症例

$$
\text { 小腸アニサキス症の } 1 \text { 例 }
$$

周南記念病院外科, JA 山口県厚生連周東総合病院外科*
上杉 尚 正
松 井 則 親* 西
健太郎”
守田知 明*

開腹手術により完全虫体を摘出しえた小腸アニサキス症の 1 例を経験したので報告す る. 症例は58歳, 男性.イワシの酢の物を食べた後より, 腹痛, 腹部膨満感, 嘔気が出 現しイレウス，腹膜炎の診断で入院した．急速なアシドーシスの進行を認め，緊急手術 を施行した．開腹した所，回腸の一部が狭察し，それより口側の回腸 $150 \mathrm{~cm}$ に息，浮 腫を認め切除した。狭窄部粘膜面に刺入し活発に活動している寄生虫 1 体を確認し，小 腸アニサキス症と診断した。

索引用語：小腸アニサキス症

\section{緒 言}

小腸アニサキス症は比較的稀な疾患で, 術前の確定 診断は一般に困難である.今回われわれは，著明なア シドーシスを認め, 緊急手術を余儀なくされた小腸ア ニサキス症の 1 例を経験したので報告する.

$$
\text { 症例 }
$$

患者：58歳, 男性.

主訴：腹痛, 腹部膨満感, 嘔吐.

既往歴：糖尿病, 狭心症で内服加療中。

現病歴：1999年 4 月19日イワシの酢の物を食べた後 より腹痛, 腹部膨満感が出現した。翌20日より腹痛激 しくなり，嘔気も伴ってきたため外来を受診し入院し た.

入院時現症：腹部は膨満し，全体に圧痛および Blumberg 徵候を認めた。

入院時血液検查所見 : 白血球数, 好酸球数は正常で あったが, CRP は14.83mg/dl と上昇していた。他, $\mathrm{BUN}$ が $48 \mathrm{mg} / \mathrm{dl}$ と上昇している以外著変を認めなか った.

腹部単純 X 線所見：著明な晹管抾張像を認めた (図 1 ).

腹部 CT 所見 : 小腸の著明な拡張と浮腫, および Kerckring 璧の肥厚を認めた（図 1 ).

血液ガス分析検査： $\mathrm{pH} 7.349, \mathrm{BE}-9.8 \mathrm{mmol} / 1$ と

2003 年 3 月 10 日受付 2003 年 4 月 9 日採用

〈所属施設住所〉

于744-0033 下松市生野屋南 1-10-1
著明なアシドーシスを認めた。

以上の所見より，イレウス，汎発性腹膜炎の診断で 緊急手術を施行した。

手術所見：開腹した所, 黄色槳液性腹水を多量に認 めた。また，回腸末端より $140 \mathrm{~cm} の$ 部位に狭燋部を認 め, それより口側の腸管は拡張し, 発赤, 浮隀, 白苔 の付着, 獎膜下出血を認めた（図 2)。よって狭窄部よ り正常部まで $150 \mathrm{~cm}$ の小腸を切除した。

摘出標本：拡張部腸管は虚血性で，粘膜譬の消失を 認めた。狭窄部腸管は強度の攀縮を認め，同部に体長 $25 \mathrm{~mm}$ の白色線状の虫体を 1 体発見した．虫体は活発 に動いてょり，腸管粘膜内にその一端を笑入させてい た(図 2).

病理組織所見：虫体は表皮抢よび筋層に被われ，腔 内には食道，中腸および肛門といった消化管構造を認 めた．脱皮前であり，アニサキス I 型第 3 期幼虫と診 断した（図 3 )。虫体が穿入していた狭窄部腸管は，全 層性に好中球を混じた炎症性細胞浸潤と高度の籍血を 認めた。また，粘膜下層域に高度の好酸球浸潤を認め た，拡張域腸管では腺窝上皮の脱落消失を認めた（图 $3)$.

以上の所見より，劇症型小腸アニサキス症と診断し た。術後 DIC を併発したが加療により軽快し, 術後32 日目に糖尿病の加療目的で内科転科した。

\section{考 察}

消化管アニサキス症は1960年に van Thiel らりによ り報告されて以来，本邦でも多数の報告例があるが， そのほとんどが罠アニサキス症で，小腸アニサキス症 


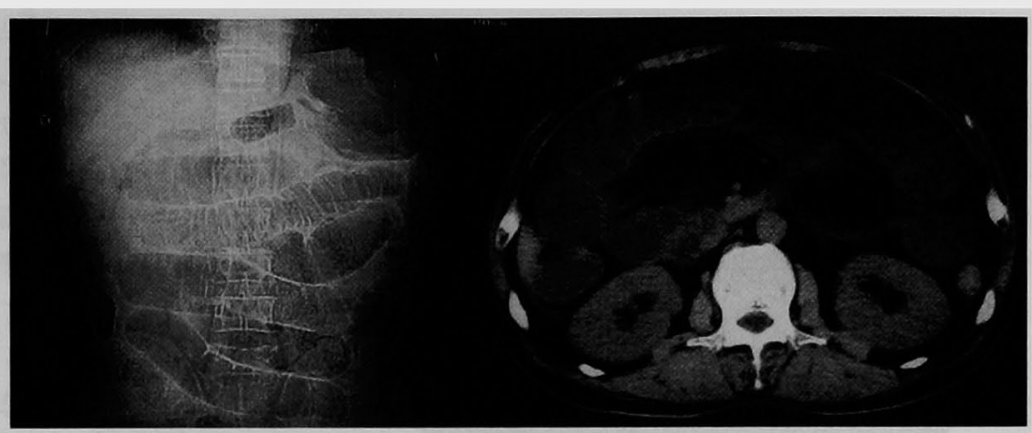

図 1 入院時画像所見：腹部単純X線写真で小腸の著明な㹡張を認めた (左). 腹 部 CT では小腸の拡張と壁肥厚を認めた（右）.

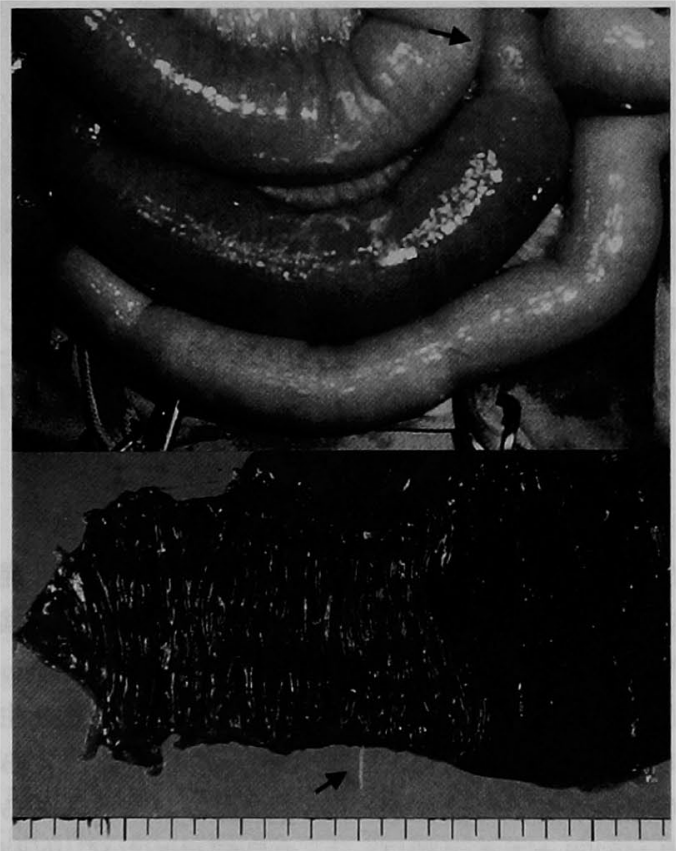

図 2 病変部所見：回腸の限局性狭菅とその口側腸 管の著明な拡張, 浮腫, 紫膜下出血, 膿苔付着を認 めた (上). 摘出標本では狭䆓部腸管に体長 $25 \mathrm{~mm}$ の白色線虫を認めた. 㹡張部腸管の粘膜は脱落し ていた（下).

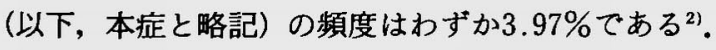
また，1963年より2003年の間に，本邦における手術に より完全虫体として摘出された本症の報告例は, 検索 しえた範囲では自験例を含め 41 例であった。術前診断 は虫垂炎, 腸閉塞, 急性腹症がほとんどで, 正診され たものは 2 例のみであった ${ }^{3)}$.その診断根拠は問診に よるものであった。

本症の発症の仕方は, 緩和型（初回感染型）と劇症
型 (再感染型) に分類される4)，前者の臨床症状は穏や かで, 病理組織学的には膿瘍, 肉芽の像を呈す。後者 はすでに感作を受けている人に起こる Arthus 型アレ ルギー反応で，臨床的には急性腹症の所見を呈し，病 理組織学的には蜂窝織炎の像を呈す. 本症手術例は全 例劇症型に分類され，開腹時所見として腸管壁の限局 性狭䆣およびその口側腸管の浮腫, 比較的多量の腹水 貯留が特徴である。 


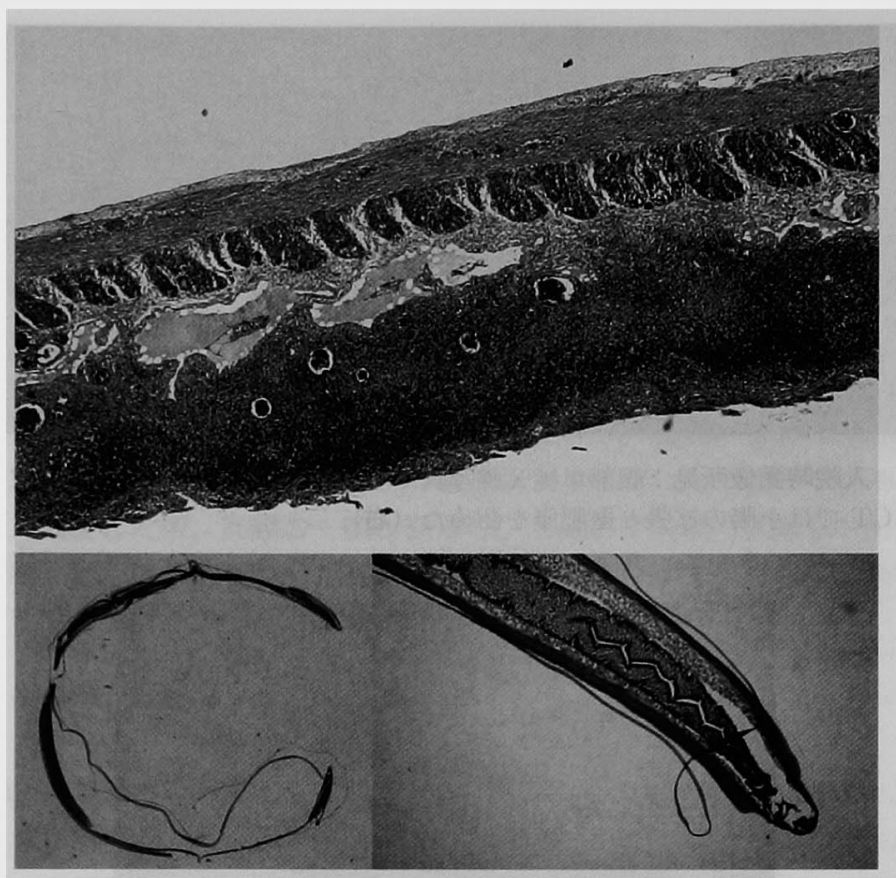

図 3 病理組織所見：小腸粘膜の脱落消失と粘膜下層を中心とした 全層性の好酸球浸潤を認めた（上， $\mathrm{HE}$ 染色， $\times 40 ）$ ．虫体に角皮， 筋層, 消化管構造を認めた (右下, $\mathrm{HE}$ 染色, $\times 40$ ・左下, $\mathrm{HE}$ 染色, $\times$ 200).

診断法については諸家が色々と報告しているが, 虫 体確認以外に確定診断法はないと考える.内視鏡的に 虫体を確認，摘出しえたとの報告例》ももるが，胃アニ サキス症と比し，本症の内視鏡診断は極めて困難であ る. 自験例はアニサキス抗体が陽性であったが，アニ サキス抗体はアニサキス既感染で陽性となり，また， 幼虫が消化管を通過しただけでも免疫される可能性が あり確診できない占．さらに，結果が判明するまで数日 を要するため, 急性腹症の診断法としての意義は少な い.

診断がつけば，軽症例に対しては対症療法で虫体は 吸収され約 1 週間で症状は消失するとされており?， 保存的治療を優先すべきとの意見が多( ${ }^{3 / 8)}$. しかし， 壊死 ${ }^{3)}$ ，穿孔9) 12)，穿通 ${ }^{13)}$ ，大量出血 ${ }^{14)}$ をたした報告 もあり，自験例のように激しい腹膜炎の症状を呈し， 著明なアシドーシスを認めるような場合，開腹は避け がたいと思われる。

牧山ら ${ }^{15)}$, 䆶田ら ${ }^{16)}$ (腸切除の適応として, 高度の腸 管内腔狭小化例, 漿膜面の膿苔付着例, 高度の局所循 環障害例を挙げている.自験例もこの適応にあてはま る. また, 本症の病変範囲は虫体刺入部を中心とし,
数 $\mathrm{cm}$ から 20 数 $\mathrm{cm}$ とされるが，自験例は $150 \mathrm{~cm}$ にわ たり小腸壁の著明な発赤浮腫, 膿苔の付着と粘膜の脱 落消失を認めた，自験例ほど広範な病変範囲を認めた 報告は見当たらなかった.

本症は，魚介類を生食する習慣のある本邦ではなく ならない疾患と考えられ，救急医療の現場で鑑別すべ き疾患の 1 つと考えられた，手術適応については種々 の見解があるが，外科医の手による触診が肝要と思わ れ，急性腹症，腹膜炎の症状を呈している場合は開腹 をためらうべきではないと考えられた。

\section{結 語}

切除した腸管粘膜に穿入し，活発に動いている虫体 を確認しえた小腸アニサキス症の1例を経験した。

\section{文 献}

1) van Thiel PH, Kuipers FC, Roskam RTH : A nematode parastic to herein, causing acute abdominal syndromes in man. Trop Geor Med $12: 97-113,1960$

2）石倉 㗨：炎症性疾患診療のポイント.アニサキ 不症. 臨消内科 $6: 1052-1056,1991$

3）高木幸浩, 阿部達彦, 佐治重豊他：急性虫垂炎と 
して開腹した小腸アニサキス症の一例. 外科治療 $67: 348-350,1992$

4）鉿木俊夫, 石倉 緊: アニサキス症の免疫学的診 断法に関する研究. 3 ・精製抗原を用いての皮内 反応，寄生虫誌 $19: 1-9,1970$

5）鉿水 隆, 平野雅弘, 中野文香他：内視鏡的に摘 出し得た回腸アニサキス症の 1 例. Gastroenterol Endosc $40: 818-822,1998$

6）石倉 聚，早坂 滉：わが国におけるアニサキス 症とその問題点. 外科 $36: 889-892,1974$

7) 伊藤聖衛, 川井和哉, 小宮 博他：イレウス症状 を呈した腸アニサキス症の一症例. 東京医大誌 $46: 377-381,1988$

8）木原 疆, 加藤祐司, 中島壮太：消化管アニサキ 不症。現代医療 $21 ： 2043-2047,1989$

9）传々木喜一, 紙田信彦, 山口善友：アニサキス症 4 例一特にアニサキス小腸穿孔例について一. 日 臨外会誌 $43: 1374-1380,1982$

10）深田伸二, 蜂須賀害多男, 山口晃弘他：イレウス
症状を来した小腸アニサキス症 3 例の检討．臨外 $39: 707-711,1984$

11）佐久間隆, 葛西 猛, 広沢邦浩他：被覆穿孔とイ レウスを伴った小腸アニサキス症の 1 例. 日救急 医会関東誌 $17: 201-211,1996$

12）丸山 章, 稲葉 鳘, 相内 晋他: 腸アニサキス 症の 2 例一Skip lesion と穿孔一. 外科診療 23 ： 517-519, 1981

13）丸山規雄, 成高義彦, 加藤博之他：アニサキスに よる小腸穿通の1例.消外 $12: 1869-1872,1989$

14）小寺泰弘, 永末裕之, 鉿木祐一他：大量消化管出 血で発症した空腸アニサキス症の 1 例. 日消外会 誌 $23: 2304-2307,1990$

15）牧山隆雄, 草野裕章, 高平良二他：腸アニサキス 症の 1 列. 日外会誌 $79: 617,1978$

16）寉田裕之, 相川公太郎, 中隆：アニサキス幼 虫による急性局所性腸炎. 胃と腸 $11: 1641-$ 1644,1976

\title{
A SURGICAL CASE OF INTESTINAL ANISAKIASIS
}

\author{
Naomasa UESUGI, Norichika MATSUI*, Kentaro NISHI* and Tomoaki MORITA* \\ Department of Surgery, Shunan Memorial Hospital \\ "Department of Surgery, Shuto General Hospital
}

We report a surgical case of intestinal anisakiasis in which we could identify a complete larva. A 58-year-old man complaining of abdominal pain, abdominal distension and nausea after eating vinegared sardines was admitted to the hospital with a diagnosis of ileus with peritonitis. An emergency operation was carried out because of rapid progress of acidosis on laboratory data. On laparotomy, severe stricture of the ileum was revealed. And congestion and dilatation of the ileum were evident at oral side of the stricture $150 \mathrm{~cm}$ in length. The affected intestine was duly resected. A vigorously moving larva of which head invaded the mucosa was found in the partially resected ileum, and we diagnosed the case as intestinal anisakiasis. 